\title{
PENGARUH FAKTOR-FAKTOR FUNDAMENTAL (CURRENT RATIO, RETURN ON ASSET, RETURN ON EQUITY, TOTAL ASSET TURN OVER, DEBT TO EQUITY RATIO, DAN ASSET GROWTH) TERHADAP BETA SAHAM SYARIAH DI BURSA EFEK INDONESIA
}

\author{
${ }^{1}$ Dewi Laraswati; ${ }^{2}$ Akbar Yusuf; ${ }^{2}$ Fitriningsih Amalo \\ ${ }^{1}$ Alumnus Program Studi Akuntansi Universitas Muhammadiyah Kupang \\ ${ }^{2}$ Program Studi Akuntansi Universitas Muhammadiyah Kupang
}

\begin{abstract}
ABSTRAKSI
Penelitian ini bertujuan untuk menganalisis pengaruh faktor fundamental perusahaan terhadap beta saham yang terdaftar di Bursa Efek Indonesia, dengan populasi dalam penelitian ini adalah seluruh perusahaan yang terdaftar di JII(Jakarta Islamic Index) tahun 2012 sampai 2016. Menggunakan purposive sampling, diperoleh sampel penelitian ini sebanyak 14 perusahaan sampel. Hasil estimasi dengan menggunakan model regresi data panel pada indekssaham JII periode 2012-2016 menunjukkan bahwa secara simultan variabelCurrent Ratio, Return on Asset, Return on Equity, Total Asset Turn Over, Debt to Equity Ratio danAsset Growth tidak berpengaruh terhadap variabel beta saham. Selain itu, secara parsial menunjukkan bahwa variabel Debt to Equity Ratio berpengaruh signifikan terhadap variabel beta saham. Sedangkan variabel Current Ratio, Return on Asset, Return on Equity, Total Asset Turn Over, dan Asset Growth tidak berpengaruh signifikan terhadap variabel beta saham.
\end{abstract}

Kata Kunci : Current Ratio, Return on Asset, Return on Equity, Total Asset Turn Over, Debt to Equity Ratio, Asset Growth, dan Risiko Sistematis (Beta)

\section{A. LATAR BELAKANG}

Pasar modal merupakan salah satu sarana atau tempat bertemunya pihak yang membutuhkan dana (Perusahaan) dengan pihak yang menyediakan dana (Investor). Pasar modal menjadi alternatif bagi perusahaan dalam memperoleh dana dari kegiatan investasi, dimana kegiatan tersebut menghubungkan permintaan dan penawaran. Setiap dana yang diinvestasikan, para investor tentunya akan menghadapi dua unsur yaitu return dan resiko. Kedua unsur tersebut saling berkaitan satu sama lain serta mempunyai timbal balik yang sebanding. Dimana semakin tinggi return yang diharapkan oleh investor dari modal yang ditanamkan, semakin tinggi pula tingkat resiko yang akan diperoleh.

Pasar modal syariah telah memainkan peran penting dalam mengubah topografi sistem keuangan dunia. Industri keuangan syariah mengalami perkembangan pesat pada beberapa dekade terakhir. Saat ini pasar modal syariah bukan lagi menjadi tren dikalangan negara muslim semata, perkembangan industri keuangan syariah yang mencapai $15 \%$ pertahun diseluruh dunia menjadikan negara-negara kapitalis dan liberal sekalipun tertarik membuka layanan pasar modal ini. Dalam konsep pertumbuhan ekonomi, pasar modal merupakan salah satu indikator pertumbuhan ekonomi dan tonggak perekonomian sebuah negara. (Antonio, Hafidhoh dan Fauzi, 2013:378).

Munculnya produk syariah di pasar modal pada mulanya berawal dari keinginan untuk mengakomodasi kebutuhan umat Islam yang ingin melakukan investasi dengan prinsip syariah. Hal inilah yang kemudian melatarbelakangi PT. Danareksa Investment Management untuk meluncurkan Danareksa Syariah pada tanggal 3 Juli 1997. Kemudian 
pada tanggal 3 Juli 2000, Bursa Efek Indonesia bekerjasama dengan PT. Danareksa Investment Management meluncurkan Jakarta Islamic Index (JII) Beik dan Fatma (2014:156). Jakarta Islamic Index atau biasa disebut JII adalah salah satu indeks saham yang ada di Indonesia yang menghitung index harga rata-rata saham untuk jenis sahamsaham yang memenuhi kriteria syariah (Utami, 2016:72).

Saham syariah merupakan salah satu bentuk dari saham biasa yang memiliki karakteristik khusus berupa kontrol yang ketat dalam hal kehalalan ruang lingkup kegiatan usaha (Aruzzi dan Bandi, 2003:649). Fatwa DSN-MUI No. 40/DSNMUI/X/2003, bab IV, pasal 4: Saham syariah merupakan bukti kepemilikan atas suatu perusahaan yang diterbitkan oleh emiten yang usahanya sesuai prinsip-prinsip syariah, dan tidak termaksud saham yang memiliki hak istimewa (Ikapi, 2009:116).

Seperti yang kita ketahui bahwa saham merupakan salah satu sekuritas yang memiliki tingkat resiko yang tinggi. Menurut Corrado and Jordan, (2000:521). Risiko memiliki dua tipe. Pertama: Risiko Sistematis ialah risiko yang mempengaruhi sejumlah besar aset. Disebut juga risiko pasar. Kedua: Risiko tak sistematis ialah risiko yang mempengaruhi perusahaan tunggal atau sekelompok kecil perusahaan. Disebut juga risiko unik.

Dalam penelitian ini akan memfokuskan pada tipe risiko pertama. Risiko sistematis ini disebut juga sebagai beta pasar (market risk), karena fluktuasinya disebabkan oleh faktor-faktor yang mempengaruhi semua perusahaan yang beroperasi (Abdurahim, 2003:46). Menurut Soeroso (2013:1689), Resiko sistematis merupakan risiko berkaitan dengan perubahan yang terjadi di luar pasar secara keseluruhan, misalnya perubahan suku bunga, inflasi, resesi ekonomi, kebijakan ekonomi secara menyeluruh, dan perubahan harapan investor terhadap perkembangan ekonomi.

Resiko sistematis terjadi diluar perusahaan dan akan mempengaruhi pasar secara keseluruhan. Dengan kata lain resiko ini diluar kendali para investor, sehingga otomatis resiko tersebut harus dihadapi. Oleh karena itu, diharapkan para investor pandai dalam membaca situasi, guna menyelamatkan dana yang ditanamkan serta mampu meminimalisasikan kerugian.

Salah satu analisis yang dapat digunakan oleh investor untuk mengetahui bagaimana kinerja suatu perusahaan adalah analisis fundamental. Menurut Herdiyana dan Sinaga (2011:1), Analisis fundamental adalah salah satu teknik analisis yang dipergunakan agar dapat memilih saham yang memberikan return yang baik sehingga investor dapat memperoleh nilai tambah dalam investasinya tanpa mengalami kerugian. Sedangkan menurut Lestari (2004:3), Analisis fundamental adalah usaha untuk memperkirakan kesehatan dan prospek, yaitu kemampuan suatu perusahaan untuk bertumbuh dan menghasilkan laba dimasa depan.

Analisis fundamental menurut Gusni (2015:37), merupakan pengujian terhadap kekuatan yang mempengaruhi kondisi ekonomi, industri dan perusahaan. Analisis terhadap kondisi ekonomi/makro umumnya fokus terhadap data-data ekonomi untuk menilai pertumbuhan ekonomi pada saat ini dan pada masa yang akan datang. Pada level industri, analisis fokus terhadap kinerja dari berbagai industri untuk mengetahui prospeknya pada masa yang akan datang. Sedangkan pada level perusahaan, analisis fundamental meliputi data-data keuangan perusahaan, manajemen, konsep bisnis dan persaingan perusahaan. Namun dalam penelitian ini analisis perusahaan akan menjadi 
fokus utama. Analisis perusahaan diproksikan oleh Current Ratio (CR), Return on Asset (ROA), Return on Equity (ROE), Total Asset Turnover (TATO), Debt to Equity Ratio (DER), dan Asset Growth (AG).

Penelitian-penelitian sebelumnya mengenai topik serupa juga sudah pernah dilakukan. Seperti Penelitian yang di lakukan oleh Aruzzi dan Bandi (2003) dengan sampel penelitian terdiri dari 30 perusahaan yang terdaftar di Bursa Efek Jakarta. Hasilnya bahwa Return on Asset dan Return on Equity tidak berpengaruh secara signifikan terhadap beta saham. Penelitian juga dilakukan oleh Soeroso (2013), dimana hasilnya bahwa Current Ratio, Total Debt Equity Ratio, dan Total Assets Turn Over berpengaruh signifikan terhadap Resiko Sistematis, sedangkan Total Debt Equity Ratio mempunyai pengaruh negatif terhadap Resiko Sistematis. Penelitian lain dilakukan oleh Jazuli dan Witiastuti (2016), populasi dalam penelitiannya adalah seluruh perusahaan sektor real estate dan property yang terdaftar di Bursa Efek Indonesia tahun 2012-2013 dengan jumlah 50 perusahaan. Hasil penelitiannya menunjukkan bahwa Current Ratio berpengaruh secara positif dan signifikan terhadap beta saham.

Chen (2014) juga meneliti faktor yang mempengaruhi risiko sistematis. Hasil penelitiannya menunjukkan bahwa Debt to Equity mempunyai hubungan yang negatif atau berlawanan dengan risiko sistematis saham. Sedangkan Asset Growth mempunyai hubungan positif dengan risiko sistematis saham. Abdurahim (2003) juga meneliti faktor yang mempengaruhi beta saham. Hasil penelitiannya menyatakan bahwa Current Ratio berpengaruh terhadap beta saham.Sedangkan Debt to Equity Ratio berpengaruh secara negatif dan tidak signifikan terhadap betasaham, Asset Gowth berpengaruh secara negatif dan signifikan terhadap beta saham. Rachmawati (2011) juga meneliti faktor yang mempengaruhi risiko sistemati. Hasil penelitiannya ialah Return on Asset merupakan faktor fundamental yang berpengaruh signifikan terhadap Beta saham. Sedangkan variable Debt to Equity Ratio merupakan faktor fundamental yang tidak berpengaruh signifikan terhadap Beta saham. Wulansari (2014) juga meneliti tentang faktor-faktor yang memengaruhi risiko sistematis. Sampel yang digunakan sebanyak 10 perusahaan di tahun 2011 dan 10 perusahaan di tahun 2012. Hasilnya menunjukkan bahwa Current Ratio dan Return on Equity mempunyai pengaruh signifikan terhadap risiko sistematik (Beta Saham).

Berdasarkan hasil penelitian terdahulu, terdapat kesenjangan mengenai pengaruh variabel independen terhadap variabel dependen. Kesenjangan tersebut diantaranya pada penelitian yang dilakukan oleh Rachmawati (2011) bahwa variabel Return on Asset berpengruh signifikan terhadap beta saham dengan koefisien korelasi negatif dan dalam penelitian Aruzzi dan Bandi (2003) menyatakan bahwa variabel Return on Asset tidak berpengruh secara signifikan terhadap beta saham dengan koefisien korelasi negatif. Sedangkan, pada hasil penelitian yang dilakukan oleh Oktodinata (2015) variabel Return on Asset berpengruh signifikan terhadap beta saham dengan koefisien korelasi positif.

Pada penelitian yang di lakukan oleh Soeroso (2013) bahwa variabel Debt to Equity Ratio berpengruh signifikan terhadap beta saham dengan koefisien korelasi positif. Berbeda dengan hasil penelitian yang dilakukan oleh Jazuli dan Witiastuti (2016) yaitu variabel Debt to Equity Ratio tidak berpengruh secara signifikan terhadap beta saham dengan koefisien korelasi negatif. Penelitian mengenai Return 
on Equity juga berbeda hasilnya. Dalam penelitian Wulansari (2015), Return on Equity mempunyai pengaruh signifikan terhadap risiko sistematik (Beta Saham). Sedangkan, hasil penelitian yang dilakukan oleh Aruzzi dan Bandi (2003) menyatakan bahwa variabel Return on Equity tidak berpengruh secara signifikan terhadap beta saham dengan koefisien korelasi negatif. Adapun penelitian mengenai Pengaruh Asset Growth terhadap beta saham yang di lakukan oleh Chen (2014) bahwa variabel tersebut memiliki pengaruh signifikan terhadap beta saham dengan koefisien korelasi positif. Di lain pihak, pada penelitian yang dilakukan oleh Jazuli dan Witiastuti (2016), Asset Growth memiliki pengaruh secara negatif dan signifikan terhadap beta saham. Sedangkan, hasil penelitian yang dilakukan oleh Oktodinata (2015), Asset Growth memiliki pengaruh secara negatif dan tidak signifikan terhadap beta saham.

Berdasarkan hasil uraian di atas dapat di tarik kesimpulan bahwa hasil penelitian mengenai pengaruh faktor fundamental khususnya Return on Asset, Return on Equity, Debt to Equity Ratio dan Asset Growth terhadap beta saham memiliki hasil yang bervariasi, menunjukan adanya kesenjangan dari hasil penelitian tersebut, sehingga memberi motivasi kepada penulis untuk melakukan penelitian lebih lanjut. Penelitian ini dilakukan untuk melanjutkan penelitian yang dilakukan oleh Aruzzi dan Bandi (2003) dengan tujuan untuk menguji adanya pengaruh faktor fundamental yang diproksikan oleh Current Ratio, Return on Asset, Return on Equity, Total Asset Turn Over, Debt to Equity Ratio, dan Asset Growth terhadap risiko sistematik atau beta saham syariah yang tergabung dalam Jakarta Islamic Index (JII) di BEI.

\section{TINJAUAN PUSTAKA}

\section{A. Faktor Fundamendal}

Analisis fundamental adalah suatu cara menganalisis saham berdasarkan kondisi kesehatan fundamental perusahaan, kondisi kesehatan industri dan kondisi kesehatan perekonomian nasional atau global dengan pisau bedah financial ratio yang umum digunakan (Sumaryono, 2013:1). Irawan (2013:2) berpendapat bahwa Analisis fundamental dilakukan oleh investor dengan menggunakan data keuangan perusahaan untuk menghitung nilai intrinsik saham, oleh karena itu laporan keungan merupakan informasi yang sangat penting, karena laporan keuangan menggambarkan aspek fundamental perusahaaan yang bersifat kuantitatif.

Wulansari (2014:4), Analisis fundamental adalah metode analisis yang didasarkan pada fundamental ekonomi suatu perusahaan. Teknik ini menitik beratkan pada rasio finansial dan kejadian-kejadian yang secara langsung maupun tidak langsung memengaruhi kinerja keuangan perusahaan. Analisis fundamental berkaitan dengan penilaian kinerja perusahaan, tentang efektifitas dan efisiensi perusahaan dalam mencapai sasarannya. Ahmad (2004:81) analisis fundamental mempelajari brosur atau data-data industry perusahaan, penjualan, kekayaan, pendapatan produk dan penyerapn pasar, evaluasi manajemen perusahaan, membandigkan dengan pesingnya, dan memperkiraka nilai intrinsic dari saham perusahaan tersebut. Analisis fundamental adalah studi tentang ekonomi, industri, dan kondisi perusahaan untuk mem perhitungkan nilai dari saham perusahaan.Analisis fundamental menitik beratkan pada data-data kunci dalam laporan 
keuangan perusahaan untuk memperhitungkan apakah harga saham sudah diapresiasikan secara akurat.Artha, Achsani, dan Sasongko (2014:177).

Berdasarkan pernyataan di atas dapat disimpulkan bahwa Analisis fundamental adalah suatu teknik yang digunakan oleh para investor untuk menilai suatu saham. Sehingga para investor dapat membandingkan nilai sesungguhnya saham dengan nilai pasar untuk menentukan harga saham yang tepat.

\section{B. Beta Saham}

Beta merupakan pengukur resiko sistematis dari suatu sekuritas atau portofolio relatip terhadap risiko pasar (Jogiyanto, 2003:266). Sedangkam menurut Aruzzi dan Bandi (2003), Beta saham merupakan hasil regresi antara return perusahaan yang dihitung dari perubahan harga saham perusahaan dengan return pasar yang dihitung dari perubahan IHSG. Risiko sistematik juga disebut dengan beta karena beta merupakan pengukur dari risiko sistematik. Risiko sistematik dapat terjadi dikarenakan faktor ekonomi makro, industri, dan karakteristik perusahaan. Untuk mengukur risiko digunakan koefisien beta. Beta suatu sekuritas merupakan hal yang penting untuk menganalisis sekuritas atau portofolio. Beta suatu sekuritas menunjukkan kepekaan tingkat keuntungan suatu sekuritas terhadap perubahan-perubahan pasar (Hamzah, 2005:367).

Berdasarkan pernyataan diatas dapat disimpulkan bahwa Beta merupakan alat ukur dari risiko sistematik untuk menganalisis sekuritas menunjukkan kepekaan tingkat keuntungan suatu sekuritas terhadap perubahan-perubahan pasar yang terjadi. Beta Saham dapat dihitung dengan rumus sebagai berikut (Aruzzi dan Bandi, 2003:652) :

$$
R_{i}=\alpha_{i}+\beta_{i} R_{M}+e_{i}
$$

Dimana, $\mathrm{R}_{\mathrm{i}}=$ return saham, $\alpha_{\mathrm{i}}=$ konstanta, $\beta_{\mathrm{i}}=$ beta saham, $e i=$ residual selama periode $\mathrm{t}$, iasumsikan $=0$, dan $\mathrm{R}_{\mathrm{M}}=$ return pasar.

Penghitungan return pasar dilakukan menggunakan persamaan, (Aruzzi dan Bandi, 2003:652). Penghitungannya adalah sebagai berikut :

$$
R_{M}=\left(R_{M t}-R_{M t-1}\right) / R_{M t-1}
$$

Dimana, $\mathrm{R}_{\mathrm{M}}=$ return pasar yang diukur dengan menggunakan data IHSG per hari, $\mathrm{R}_{\mathrm{Mt}}=\mathrm{IHSG}$ pada periode $\mathrm{t}$, dan $\mathrm{R}_{\mathrm{Mt}-1}=\mathrm{IHSG}$ pada periode $\mathrm{t}-1$.

Untuk return saham $\mathrm{R}_{\mathrm{i}}$ dihitung berdasarkan harga saham individual bulanan (Rahmawati, 2005:313). Penghitungannya adalah sebagai berikut :

$$
R_{i}=\left(P_{i t}-P_{i t-1}\right) / P_{i t-1}
$$

Dimana, $\mathrm{R}_{\mathrm{i}} \quad=$ return saham, $\mathrm{P}_{\mathrm{it}} \quad=$ harga saham penutupan periode $\mathrm{t}$, dan $\mathrm{P}_{\mathrm{it}-1}=$ harga saham penutupan pada periode $\mathrm{t}-1$.

\section{Pasar Modal Syariah}

Pasar modal syariah adalah pasar modal yang dijalankan dengan konsep syariah, dimana setiap perdagangan surat berharga mentaati ketentuan transaksi sesuai dengan basis syariah (Hamzah, 2005:368). Pasar modal syariah menurut Firdaus (2013:6) merupakan salah satu implementasi konkrit dari ekonomi syariah. Ibarat sebuah rumah ekonomi syariah maka pasar modal syariah sebagai salah satu ruangan diantara beberapa 
ruang yang lain seperti bank syariah, akuntansi syariah, reksa dana syariah, asuransi syariah dan lain-lain. Oleh karena itu, pasar modal syariah tidak dapat dilepaskan dari ekonomi syariah. Fondasi filosofis yang menjadi dasar operasional pasar modal syariah adalah ekonomi syariah.

Berdasarkan pernyataan di atas dapat disimpulkan bahwa pasar modal syariah merupakan tempat dilakukannya kegiatan permintaan dan penawaran surat-surat berharga. Dimana setiap pihak harus mentaati ketentuan transaksi sesuai dengan basis syariah.

\section{KERANGKA BERPIKIR}

1. Pengaruh Current Ratio (CR) terhadap Beta Saham

Current ratio merupakan perbandingan antara aktiva lancar dengan hutang lancar. Current ratio yang tinggi memberikan gambaran bahwa perusahaan memiliki kemampuan untuk melunasi kewajibannya yang telah jatuh tempo. Akan tetapi Current ratio yang terlalu tinggi menggambarkan bahwa modal kerja perusahaan tidak berputar atau mengalami pengangguran. Hal tersebut akan mengurangi kemampuan perusahaan dalam memperoleh laba dengan kata lain current ratio berpengaruh positif terhadap resiko sistematis.

$\mathrm{H}_{\mathrm{a} 1}$ : Current Ratio (CR) berpengaruh positif dan signifikan terhadap beta saham;

\section{Pengaruh Return on Asset (ROA) terhadap Beta Saham}

Return on asset ialah rasio yang mengukur kemampuan perusahaan dalam menghasilkan laba dari aktiva yang dipergunakan. Apabila return on asset meningkat, maka tingkat pengembalian (return) yang diharapkan juga akan meningkat. Semakin tinggi return yang diperoleh maka semakin tinggi pula kemungkinan tingkat resiko yang akan dihadapi.

$\mathrm{H}_{\mathrm{a} 2}$ : Return on Asset (ROA) berpengaruh positif dan signifikan terhadap beta saham;

3. Pengaruh Return on Equity (ROE) terhadap Beta Saham

Return on equity ialah rasio yang mengukur tingkat penghasilan bersih yang diperoleh oleh suatu perusahaan atas modal yang dimiliki. Semakin tinggi return on equity mengambarkan semakin baik keadaan perusahaan. Hal tersebut akan meningkatkan kepercayaan para investor untuk menanamkan modalnya. Akan tetapi jika return on equitynya rendah, maka hilang kepercayaan investor terhadap perusahaan tersebut. Dengan demikian return on equity berpengaruh positif terhadap resiko sistematis.

$\mathrm{H}_{\mathrm{a} 3}$ : Return on Equity (ROE) berpengaruh positif dan signifikan terhadap beta saham; 4. Pengaruh Total Asset Turn Over (TATO) terhadap Beta Saham

Total asset turnover adalah rasio yang digunakan untuk mengukur perputaran semua aktiva yang dimiliki perusahaan dan mengukur berapa jumlah penjualan yang diperoleh. Nilai total asset turnover yang semakin besar menunjukkan nilai penjualan yang besr pula. Penjualan yang tinggi akan mengakibatkan laba yang tinggi pula, sehingga berpengaruh pada return yang tentunya member pengaruh positif terhadap resiko sistematis.

$\mathrm{H}_{\mathrm{a} 4}$ : Total Asset Turnover (TATO) berpengaruh positif dan signifikan terhadap beta saham; 


\section{Pengaruh Debt to Equity Ratio (DER) terhadap Beta Saham}

Debt to equity ratio menggambarkan sampai sejauh mana modal pemilik dapat menutupi hutang-hutangnya. Hal tersebut menunjukkan bahwa penggunaan Debt to Equity Ratio bertujuan agar harapan perusahaan dalam memperoleh keuntungan lebih besar dari biaya tetap yang harus dibayar. Jika keuntungan yang dimiliki perusahaan lebih kecil dibandingkan dengan biaya tetap maka laba yang diperoleh menjadi berkurang serta akan mempengaruhi dividen yang diterima oleh investor. Prospek perusahaan yang semakin menurun akan menyebabkan berkurangnya harapan investor dalam berinvestasi, sehingga tingkat resiko yang akan ditanggung oleh perusahaan semakin besar.

$\mathrm{H}_{\mathrm{as}}$ : Debt to Equity Ratio (DER) berpengaruh positif dan signifikan terhadap beta saham;

6. Pengaruh Asset Growth (AG) terhadap Beta Saham

Semakin tinggi asset growth berarti peluang untuk mengadakan ekspansi perusahaan tersebut telah dimanfaatkan tentu dengan asumsi dalam mengadakan ekspansi telah dipertimbangkan dengan matang. Ekspansi akan dilakukan manakala dapat menaikan rate of return sehingga diprediksikan mempunyai hubungan positif dengan beta (Muljono, 2002:31).

Perusahaan yang memiliki tingkat pertumbuhan aset yang cepat menggambarkan bahwa adanya ekspansi yang sedang dilakukan oleh perusahaan tersebut. Jika ekspansi ini tidak berhasil, maka beban yang harus ditanggung oleh perusahaan akan meningkatkan. Apabila beban terlalu tinggi akan menyebabkan para investor menarik sahamnya karena turunnya harapan para pemodal serta menurunnya minat investor yang pada awalnya ingin menanamkan modal pada perusahaan tersebut. Hal ini menyebabkan perubahan terhadap return saham sehingga berakibat pada beta saham perusahaan.

$\mathrm{H}_{\mathrm{a} 6}$ : Asset Growth (AG) berpengaruh positif dan signifikan terhadap beta saham;

$\mathrm{H}_{\mathrm{a} 7}$ : Current Ratio (CR), Return on Asset (ROA), Return on Equity (ROE), Total Asset Turnover (TATO), Debt to Equity Ratio (DER), dan Asset Growth (AG) berpengaruh secara simultan terhadap beta saham.

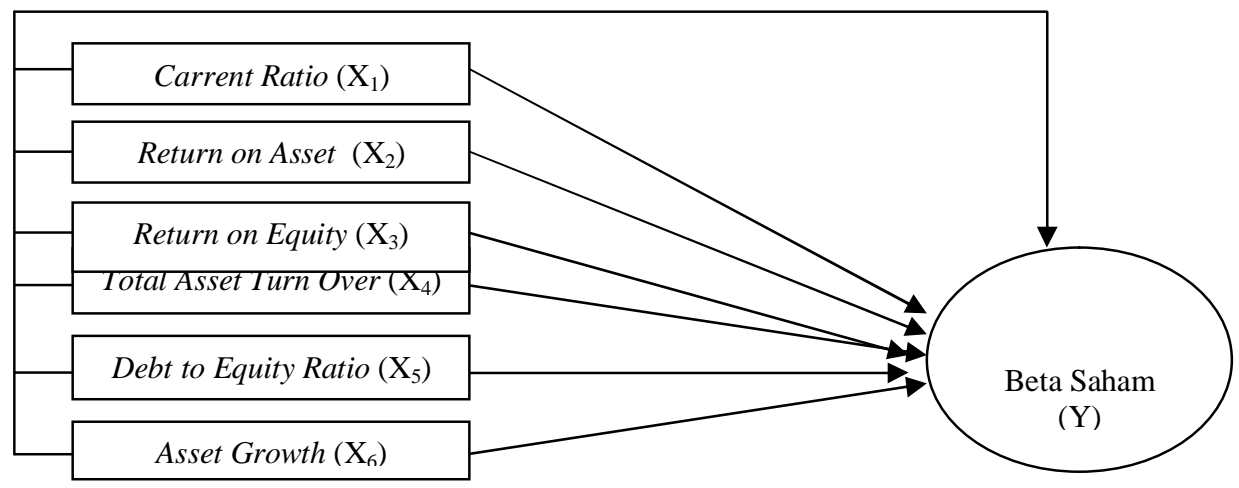

Gambar 1. Kerangka Pemikiran (Sumber: Olahan Penilis, 2017)

\section{METODE PENELITIAN}

\section{A. DESAIN PENELITIAN}

Penelitian ini dilakukan dengan menguji hipotesis untuk menetuknan tingkat dimana variabel-variabel yang diteliti berhubungan satu sama lain. Dalam penelitian 
ini, desain risetnya digunakan data panel. Data Panel merupakan gabungan dari data cross-section dan time series (Pusakasari, 2015:477). Struktur data yang digunakan yaitu struktur data balanced.

\section{B. TEKNIK PENGAMBILAN SAMPEL}

Adapun teknik penentuan sampel dalam penelitian ini adalah teknik purposive sampling, yaitu teknik penentuan sampel dengan pertimbangan kriteria-kriteria tertentu (Aruzzi dan Bandi, 2003:651), yaitu:

1. Fokus penelitian merupakan saham emiten yang listing di BEI;

2. Data keuangan diperoleh dari beberapa perusahaan yang secara konsisten terdaftar dalam Jakarta Islamic Index; dan

3. Perusahaan yang memiliki laporan keuangan tahunan yang lengkap pada tahun 2012-2016.

\section{POPULASI DAN SAMPEL}

Populasi penelitian ini adalah perusahaan yang terdaftar di Jakarta Islamic Index (JII) periode 2012-2016 pada Bursa Efek Indonesia (BEI). Sesuai dengan pengumuman Bursa Efek Indonesia No.: Peng-00917/BEI.OPP/11-2016 tanggal 29. Terdapat 30 saham yang masuk dalam perhitungan indeks Jakarta Islamic Index (JII). Dalam penelitian ini sampel yang diambil yaitu perusahaan-perusahaan yang berturut-turut terdaftar di JII periode 2012-2016 sebanyak 14 perusahaan.

\section{DEFINISI OPERASIONAL DAN PENGUKURAN VARIABEL}

\section{Variabel Independen}

Variabel independen merupakan variabel stimulus atau variabel yang mempengaruhi variabel lain (Sarwana dan Martadiredja, 2008:107). Variabel independen yang digunakan yaitu faktor fundamental yang diproksikan oleh Current Ratio, Return on Asset, Return on Equity, Total Asset Turn Over, Debt to Equity Ratio, dan Asset Growth.

a. Current Ratio: Rasio ini menunjukkan kemampuan untuk melunasi kewajiban-kewajiban finansial jangka pendeknya (Rhamadana, 2016:6);

b. Return on Asset: Rasio ini menunjukkan kemampuan perusahaan dalam menghasilkan laba bersih dari total aset perusahaan (Zuhro, 2016:6);

c. Return on Equity: Rasio ini mengukur seberapa banyak keuntungan yang menjadi hak pemilik modal sendiri (Husnan, 1998:564);

d. Total Asset Turn Over: Rasio ini mengukur perputaran dari semua aset yang dimiliki perusahaan. Total assets turnover dihitung dari pembagian antara penjualan dengan totalasetnya (Rhamadana, 2016:7);

e. Debt to Equity Ratio: Rasio ini menggambarkan sampai sejauh mana modal pemilik dapat menutupi hutang-hutang pada pihak luar (Pramono, 2015:6); dan

f. Asset Growth: Rasio ini untuk mengukur seberapa besar kemampuan perusahaan dalam mempertahankan posisinya di dalam industru dan dalam perkembangan ekonomi secara umum (Fahmi, 2013:137). 


\section{Variabel Dependen}

Variabel Dependen adalah variabel yang memberikan reaksi/respons jika dihubungkan dengan variabel bebas (Sarwana dan Martadiredja, 2008:107).

Beta saham merupakan hasil regresi antara return perusahaan yang dihitung dari perubahan harga saham perusahaan pada akhir bulan dengan return pasar yang dihitung dari perubahan IHSG setiap akhir bulan (Aruzzi dan Bandi, 2003:653).

Tabel 1. Variabel dan Pengukurannya

\begin{tabular}{|c|c|c|}
\hline Variabel & Indikator & Skala \\
\hline $\begin{array}{l}\text { Current Ratio } \\
\left(\mathrm{X}_{1}\right)\end{array}$ & Rasio Lancar $=\begin{array}{c}\text { Aktiva Lancar } \\
\text { Kewajiban Lancar }\end{array}$ & Rasio \\
\hline $\begin{array}{l}\text { Return on Asset } \\
\left(\mathrm{X}_{2}\right)\end{array}$ & $\begin{array}{c}\text { Return on Asset }=\begin{array}{c}\text { Laba Bersih setelah paja } \\
\text { Aktiva Total }\end{array} \\
\end{array}$ & Rasio \\
\hline Return on Equity $\left(\mathrm{X}_{4}\right)$ & $\begin{array}{r}\text { Return on Equity = Laba Bersih setelah pajak } \\
\text { Modal Sendiri }\end{array}$ & Rasio \\
\hline $\begin{array}{c}\text { Total Asset Turn Over } \\
\left(\mathrm{X}_{5}\right)\end{array}$ & $\begin{aligned} \text { Perputaran Aktiva }= & \begin{array}{l}\text { Penjualan } \\
\text { Total Aset }\end{array}\end{aligned}$ & Rasio \\
\hline $\begin{array}{l}\text { Debt To Equity Ratio } \\
\left(\mathrm{X}_{6}\right)\end{array}$ & $\begin{array}{rr}\text { Debt to Equity Ratio }=\begin{array}{r}\text { Total Utang } \\
\text { Total Modal }\end{array} \\
\end{array}$ & Rasio \\
\hline $\begin{array}{l}\text { Asset Growth } \\
\left(\mathrm{X}_{7}\right) \\
\end{array}$ & 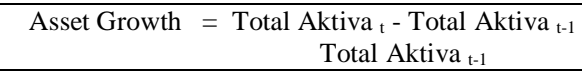 & Rasio \\
\hline $\begin{array}{l}\text { Beta Saham } \\
\text { (Y) }\end{array}$ & $\begin{array}{l}R_{i}=\alpha_{i}+\beta_{i .} R_{m}+e_{i} \\
R_{M}=R_{M t}-R_{M t-1} / R_{M t-1} \\
P_{t}=P_{i t}-P_{i t-1} / P_{i t-1}\end{array}$ & Rasio \\
\hline
\end{tabular}

Sumber: Olahan Penulis (2017)

\section{E. TEKNIK ANALASIS DATA}

\section{Analisis Regresi}

Analisis data seluruh model persamaan regresi dalam penelitian ini menggunakan paket program SPSS. Analisis regresi linear berganda digunakan untuk menjelaskan hubungan antara satu variabel dependen dengan lebih dari satu variabel independen (Aruzzi dan Bandi, 2003).

$$
\mathrm{Y}=\alpha+\mathrm{b}_{1} . \mathrm{X}_{1}+\mathrm{b}_{2} . \mathrm{X}_{1}+\mathrm{b}_{2} . \mathrm{X}_{2}+\mathrm{b}_{4} \cdot \mathrm{X}_{4}+\mathrm{b}_{5} \cdot \mathrm{X}_{5}+\mathrm{b}_{\kappa} . \mathrm{X}_{\kappa}+\mathrm{e}
$$

Sumber : Atmaja (2009:177)

Keterangan:

$\mathrm{Y}=$ Beta Saham

$\mathrm{X}_{1}=$ Current Ratio

$\mathrm{X}_{2}=$ Return on Asset

$\mathrm{X}_{3}=$ Return on Equity

$\mathrm{X}_{4}=$ Total Asset Turn Over

$\mathrm{X}_{5}=$ Debt to Equity Ratio

$\mathrm{X}_{6}=$ Asset Growth

$\mathrm{e}=$ Kesalahan Prediksi (error)

$\mathrm{b}_{1}, \mathrm{~b}_{2,}, \mathrm{~b}_{3,} \mathrm{~b}_{4}, \mathrm{~b}_{5}$, dan $\mathrm{b}_{6}$ merupakan koefisien regresi

\section{Pengujian Pengaruh Variabel Independen Secara Simultan (Uji F)}

Untuk mengetahui seberapa besar pengaruh variabel independen terhadap variabel dependen. Uji $\mathrm{F}$ adalah uji yang dilakukan untuk membuktikan pengaruh variabelvariabel bebas secara keseluruhan terhadap variabel terikat pada analisis regresi. 
Pengujian dilakukan pada uji $\mathrm{F}$ dengan tingkat keyakinan 95\%. Dasar pengambilan keputusan dengan melihat tingkat probabilitas (Ming Chen, 2014).

Jika probabilitas < $0.05: \mathrm{H} 0$ ditolak dan Ha diterima

Jika probabilitas > $0.05: \mathrm{H} 0$ diterima dan Ha ditolak

\section{HASIL PENELITIAN DAN PEMBAHASAN}

\section{A. Deskriptif Statistik}

Berdasarkan tabel 4.21 diketahui bahwa $\mathrm{N}$ merupakan jumlah data yang diolah peneliti yaitu terdiri dari variabel Current Ratio, Return on Asset, Return on Equity, Total Asset Turn Over, Debt to Equty Ratio, Asset Growth dan Beta Saham. Jumlah sampel yang diolah yaitu 14 dari 30 perusahaan yang terdaftar dalam JII (Jakarta Islamic Index) periode 2012-2016.

Tabel 2. Deskriptif Statistik

\begin{tabular}{lrrrrr}
\hline & N & Minimum & Maximum & Mean & Std. Deviation \\
& & & & & \\
\hline CR & 70 & 45.00 & 691.00 & 237.3000 & 158.78719 \\
ROA & 70 & 2.00 & 41.00 & 12.4299 & 9.37760 \\
ROE & 70 & 4.00 & 135.00 & 24.3143 & 28.79943 \\
TATO & 70 & 21.00 & 241.00 & 90.9286 & 56.42061 \\
DER & 70 & 0.02 & 255.00 & 82.0571 & 58.62306 \\
AG & 70 & -30.00 & 100.00 & 12.9571 & 15.46144 \\
Beta & 70 & -1.48 & 3.17 & .9500 & .92862 \\
Valid N (listwise) & & & & &
\end{tabular}

Sumber: Data sekunder yang diolah menggunakan SPSS 16 (2017)

Nilai rata-rata yaitu 237,3000 yang berarti rata-rata kemampuan perusahaan dalam melunasi kewajiban-kewajiban jangka pendek sebesar 237,3000, dengan standar deviasi 158,78719. Nilai rata-rata Current Ratio > standar deviasi yang berarti sebaran nilai Current Ratio baik.

Return on Asset dengan nilai rata-rata 12,4299, yang berarti rata-rata kemampuan perusahaan dalam dalam menghasilkan laba dari total asset yang dimiliki sebesar 12,4299. Rata-rata Return on Equity sebesar 24,3143 yang berarti rata-rata kemampuan perusahaan dalam meningkatkan laba besih dari modal sendiri sebesar 24,3143. Total Asset Turn Over memberikan nilai rata-rata 90,9286 yang berarti rata-rata kemampuan perusahaan dalam dalam menghasilkan laba dari total asset yang dimiliki sebesar 90,9286. Debt to Equity Ratio memberikan nilai rata-rata 82,0571 yang berarti rata-rata kemampuan modal perusahaan sendiri dalam menutupi hutang-hutang pada pihak luar sebesar 82,0571. Asset Growth sebesar memberikan nilai rata-rata 12,9571 yang berarti rata-rata kemampuan perusahaan dalam meningkatkan laba besih tahun sekarang dibanding laba besih tahun lalu sebesar 12,9571.

\section{B. Hasil Regresi Berganda}

Hasil uji statistik-t pada Tabel 3 menunjukan bahwa variabel Current Ratio memiliki nilai signifikan $0,659>0,05$ dan $t_{\text {hitung }}$ sebesar $-0,443<1,999$ ( $\left.\mathrm{t}_{\text {tabel }}\right)$ dengan koefisien korelasi 0,000. Pada variabel Return on Asset memiliki nilai signifikan $0,150>0,05$ dan $\mathrm{t}_{\text {hitung }}$ sebesar $1,458<1,999\left(\mathrm{t}_{\text {tabel }}\right)$ dengan koefisien korelasi 0,038 . Return on Equity memiliki nilai signifikan $0,042<0,05$ dan $t_{\text {hitung }}$ sebesar $-2,078<1,999$ ( $\mathrm{t}_{\text {tabel }}$ ) 
dengan koefisien korelasi -0,022. Pada variabel Total Asset Turn Over memiliki nilai signifikan $0,476>0,05$ dan $\mathrm{t}_{\text {hitung }}$ sebesar $-0,717<1,999\left(\mathrm{t}_{\text {tabel }}\right)$ dengan koefisien korelasi 0,002. Pada variabel Debt to Equity Ratio memiliki nilai signifikan 0,030<0,05 dan $\mathrm{t}_{\text {hitung }}$ sebesar 2,221>1,999 $\left(\mathrm{t}_{\text {tabel }}\right)$ dengan koefisien korelasi 0,003. Pada variabel Asset Growth nilai signifikannya sebesar $0,917>0,05$ dan $t_{\text {hitung }}$ sebesar $-0,104<1,999\left(t_{\text {tabel }}\right)$ dengan koefisien korelasi 0,000.

Tabel 3. Pengujian Pengaruh Variabel Independen Secara Parsial

\begin{tabular}{lrrr}
\hline \multicolumn{1}{c}{ Variabel } & $\begin{array}{c}\text { Unstandardized } \\
\text { Coefficients } \text { (B) }\end{array}$ & \multicolumn{1}{c}{ T } & Sig. \\
\hline (Constant) & 0.798 & 2.046 & 0.045 \\
X_CR & 0.000 & -0.433 & 0.659 \\
X_ROA & 0.038 & 1.458 & 0.150 \\
X_ROE & -0.022 & -2.078 & 0.042 \\
X_TATO & -0.002 & -0.717 & 0.476 \\
X_DER & 0.006 & 2.221 & 0.030 \\
X_AG & 0.000 & -0.104 & 0.917 \\
\hline
\end{tabular}

Sumber: Olahan Penulis (2017)

Persamaan regresi dapat ditulis sebagai berikut:

$$
\begin{aligned}
\mathrm{Y}= & 0,798+0,000 \mathrm{CR}+0,038 \mathrm{ROA}-0,022 \mathrm{ROE}-0,002 \mathrm{TATO}+ \\
& \text { 0,006DER + 0,000AG }
\end{aligned}
$$

Koefisien regresi pada current ratio diperoleh sebesar 0,000. Dapat disimpulkan bahwa setiap peningkatan sebesar satu satuan current ratio (X1) maka beta saham akan mengalami peningkatan sebesar 0,000 satuan. Pada return on asset diperoleh koefisien regresi sebesar 0,038 . Hal ini menyatakan bahwa setiap peningkatan sebesar satu satuan return on asset (X2) maka beta saham akan mengalami peningkatan sebesar 0,038 satuan. Koefisien regresi return on equity diperoleh sebesar -0,022. Dapat disimpulkan bahwa setiap penurunan sebesar satu satuan return on equity (X3) maka beta saham akan mengalami penurunan sebesar $-0,022$ satuan. Sedangkan total asset turn over diperoleh koefisien regresi sebesar -0,002. Hal ini menyatakan bahwa setiap penurunan sebesar satu satuan total asset turn over (X4) maka beta saham akan mengalami penurunan sebesar 0,002 satuan. Pada debt to equity ratio diperoleh koefisien regresi sebesar 0,006. Dapat disimpulkan bahwa setiap peningkatan sebesar satu satuan debt to equity ratio (X5) maka beta saham akan mengalami peningkatan sebesar 0,006 satuan. Sedangkan pada asset growth diperoleh koefisien regresi sebesar 0,000. Hal ini menyatakan bahwa setiap peningkatan sebesar satu satuan asset growth (X6) maka beta saham akan mengalami peningkatan sebesar 0,000 satuan.

\section{Pembahasan Hasil Penelitian}

Hipotesis pertama menyatakan bahwa current ratio memiliki pengaruh positif dan signifikan terhadap beta saham syariah. Berdasarkan hasil analisis pada tabel 4.28 dapat diketahui bahwa pengaruh current ratio terhadap beta saham syariah memiliki nilai koefisien korelasi positif $(0,000)$ dan tidak signifikan $0,659>0,05$. Hal ini berarti current ratio tidak memiliki pengaruh terhadap beta saham dan tidak signifikan sehingga $\mathrm{H}_{\mathrm{a}}$ ditolak. Meskipun nilai pada koefisien korelasi bernilai positif tetapi angka koefisien korelasi 0,000 yang berarti setiap peningkatan sebesar satu satuan current ratio akan meningkatan beta saham sebesar 0,000. Dapat disimpulkan bahwa current ratio tidak memiliki pengaruh terhadap beta saham. 
Alasan tidak berpengaruh current ratio terhadap beta saham ialah dikarenakan data yang digunakan sebagai sampel merupakan perusahaan-perusahaan syariah terlikuid. Perusahaan yang memiliki tingkat likuiditas yang tinggi menggambarkan perusahaanperusahaan yang memiliki kemampuan dalam melunasi kewajiban-kewajiban jangka pendeknya. Hal ini berarti perusahaan-perusahaan tersebut memiliki kinerja yang baik, dikarenakan perusahan-perusahaan tersebut memiliki peluang untuk bekerja sama dengan pihak luar seperti kreditor dan pemasok.

Coryaina (2013:27) berpendapat bahwa likuiditas yang tinggi akan memperkecil risiko kegagalan perusahaan dalam memenuhi kewajiban jangka pendek terhadap kreditur. Hasil penelitian ini mendukung penelitian Coryaina (2013), dimana current ratio tidak berpengaruh terhadap beta saham dan menolak penelitian yang di lakukan oleh Jazuli dan Witiastuti (2016) yang menyatakan bahwa current ratio berpengaruh positif signifikan terhadap beta saham.

Hipotesis kedua menyatakan bahwa return on asset memiliki pengaruh positif dan signifikan terhadap beta saham syariah. Berdasarkan hasil analisis pada tabel 4.28 dapat diketahui bahwa pengaruh return on asset terhadap beta saham syariah memiliki nilai koefisien korelasi positif $(0,038)$ dan tidak signifikan $0,150>0,05$. Hal ini berarti return on asset tidak memiliki pengaruh signifikan terhadap beta saham dengan koefisien korelasi positif sehingga $\mathrm{H}_{\mathrm{a} 2}$ ditolak. Hasil penelitian ini mendukung penelitian Aruzzi dan Bandi (2013) yang menyatakan bahwa return on asset tidak berpengaruh secara signifikan terhadap beta saham dan menolak penelitian yang dilakukan oleh Oktodinata (2015), dimana return on asset berpengaruh signifikan terhadap beta saham dengan koefisien korelasi positif.

Prestasi perusahaan dapat dinilai menggunakan rasio profitabilitas berupa return on asset. Return on asset merupakan alat ukur untuk menilai kemampuan perusahaan dalam menghasilkan laba. Semakin tinggi rasio ini menggambarkan bahwa perusahaan mampu memenuhi kewajiban bagi para invesntor.

Rahman (2015) berpendapat salah satu indikator penting untuk menilai prospek perusahaan dimasa yang akan datang dengan melihat prospek pertumbuhan profitabilitas perusahaan. Indikator ini sangat penting di perhatikan untuk mengetahui probabilitas investasi yang akan dilakukan suatu perusahaan apakah mampu memberikan return yang sesuai dengan tingkat yang dipersyaratkan investor.

Hipotesis ketiga menyatakan bahwa return on equity memiliki pengaruh positif dan signifikan terhadap beta saham syariah. Berdasarkan hasil analisis pada tabel 4.28 dapat diketahui bahwa pengaruh return on equity terhadap beta saham syariah memiliki nilai koefisien korelasi negatif $(-0,022)$ dan signifikan $0,042<0,05$. Dapat disimpulkan bahwa return on equity tidak memiliki pengaruh yang signifikan terhadap beta saham dengan koefisien korelasi negatif sehingga $\mathrm{H}_{23}$ ditolak. Hasil penelitian ini mendukung penelitian Aruzzi dan Bandi (2013) yang menyatakan bahwa return on equity tidak berpengaruh secara signifikan terhadap beta saham dengan koefisien korelasi negative dan menolak penelitian yang dilakukan oleh Wulansari (2014), dimana return on equity berpengaruh signifikan terhadap beta saham.

Chairiyah (2013:16) berpendapat bahwa "Investor biasanya akan mempertimbangkan perusahaan yang mampu memberikan kontribusi return on equity yang lebih tingg. Dari sudut pandang investor return on equity merupakan salah satu 
indikator penting untuk menilai prospek perusahaan di masa mendatang dan investor dapat melihat sejauh mana pertumbuhan profitabilitas perusahaan.

Return on equity memiliki peran penting sebagai indikator utuk memastikan kinerja suatu perusahaan dalam mengelola ekuitasnya. Hal ini berdampak pada pihak luar seperti investor maupun calon investor. Dimana para investor dapat menggunaankan rasio ini sebagai alat ukur terhadap pengembalian laba. Perusahaan dengan nilai return on equity yang tinggi akan menarik minat investor dalam menanamkan modalnya sehingga beresiko kecil. Semakin tinggi return on equity akan mengakibatkan beta saham tersebut semakin rendah sebaliknya bila return on equity rendah akan mengakibatkan beta sahamnya semakin tinggi

Pada hipotesis keempat menyatakan bahwa total asset turn over memiliki pengaruh positif dan signifikan terhadap beta saham syariah. Berdasarkan hasil analisis pada tabel 4.28 dapat diketahui bahwa pengaruh total asset turn over terhadap beta saham syariah memiliki nilai koefisien korelasi negatif $(-0,002)$ dan tidak signifikan $0,476>0,05$. Dapat disimpulkan bahwa total asset turn over tidak memiliki pengaruh terhadap beta saham sehingga $\mathrm{H}_{\mathrm{a} 4}$ ditolak. Hasil penelitian ini mendukung penelitian Prakosa (2012), dimana total asset turn over berpengaruh negatif dan tidak signifikan dan menolak penelitian yang dilakukan oleh Soeroso (2013) yang menyatakan bahwa debt to equity ratio berpengaruh secara signifikan terhadap beta saham dengan koefisien korelasi positif.

Beberapa alasan mengapa total asset turnover tidak berpengaruh terhadap beta saham dikarena perusahaan yang diteliti memiliki nilai total asset turnover dengan standar "sangat baik". Hal ini menggambarkan perusahaan-perusahaan tersebut telah menggunakan asetnya dengan produktif, sehingga tidak terdapat aset yang mengganggur. Artinya, perusahaan sudah efektif dalam menggunakan asset-asetnya.

Hipotesis kelima menyatakan bahwa debt to equity ratio memiliki pengaruh positif dan signifikan terhadap beta saham syariah. Berdasarkan hasil analisis pada tabel 4.28 dapat diketahui bahwa pengaruh debt to equity ratio terhadap beta saham syariah memiliki nilai koefisien korelasi positif $(0,006)$ dan signifikan $0,030<0,05$. Dapat disimpulkan bahwa debt to equity ratio memiliki pengaruh yang signifikan terhadap beta saham dengan koefisien korelasi positif sehingga $\mathrm{H}_{\mathrm{a} 5}$ diterima. Hasil penelitian ini mendukung penelitian Soeroso (2013), dimana debt to equity ratio berpengaruh signifikan terhadap beta saham dengan koefisien korelasi positif dan menolak penelitian yang dilakukan oleh Witiastuti (2016) yang menyatakan bahwa debt to equity ratio tidak berpengaruh secara signifikan terhadap beta saham dengan koefisien korelasi negatif.

Beberapa alasan berpengaruh debt to equity ratio terhadap beta saham dikarenakan semakin tinggi nilai debt to equity ratio menggambarkan besarnya proporsi penggunaan utang dalam pembiayaan investasi. Semakin tinggi nilai debt to equity ratio menggambarkan penggunaan utang yang besar sehingga beta saham akan meningkat, hal ini dikarenakan perusahaan beresiko tidak mampu membayar utang-utang tersebut.

Pada hipotesis keenam menyatakan bahwa asset growth memiliki pengaruh positif dan signifikan terhadap beta saham syariah. Berdasarkan hasil analisis pada tabel 4.28 dapat diketahui bahwa pengaruh asset growth terhadap beta saham syariah memiliki nilai koefisien korelasi negatif $(0,000)$ dan tidak signifikan 0,917>0,05. Dapat disimpulkan bahwa asset growth tidak memiliki pengaruh terhadap beta saham sehingga 
$\mathrm{H}_{\mathrm{a} 6}$ ditolak. Meskipun nilai pada koefisien korelasi bernilai positif tetapi angka koefisien korelasi 0,000 yang berarti setiap peningkatan sebesar satu satuan asset growth akan meningkatan beta saham sebesar 0,000. Hal ini berarti current ratio tidak memiliki pengaruh terhadap beta saham.

Perusahaan yang memiliki tingkat pertumbuhan aset yang cepat menggambarkan bahwa adanya ekspansi yang sedang dilakukan oleh perusahaan tersebut. Jika ekspansi ini tidak berhasil, maka beban akan meningkat, dikarenakan untuk menutupi pengembalian biaya ekspansi.

Alasan tidak berpengaruh asset growth terhadap beta saham ialah dikarenakan pada perusahaan yang diteliti dari tahun ke tahun memiliki tingkat pertumbuhan asset yang lambat. Dapat dilihat pada tabel 4.21 diatas, bahwa nilai rata-rata pada asset growth sebesar 12,9571 yang berarti rata-rata kemampuan perusahaan dalam meningkatkan laba besih tahun sekarang dibanding laba besih tahun lalu sebesar 12,9571. Pembuktian lain dapat dilihat pada tabel 4.17 dari tahun ke tahun tidak ada perusahaan yang memiliki kriteria "sangat baik" atau "baik". Hal ini berarti nilai pertumbuhan asset masih terbilang lambat. Dapat disimpulkan bahwa jenis saham saham yang terdaftar dalam JII (Jakarta Islamic Index) periode 2012-2016 tidak sedang melakukan ekspansi.

Hasil penelitian ini mendukung penelitian Oktodinata (2015), dimana asset growth tidak berpengaruh signifikan terhadap beta saham dan menolak penelitian yang dilakukan oleh Chen (2014) yang menyatakan bahwa asset growth berpengaruh positif signifikan terhadap beta saham.

Pada hipotesis ketujuh menyatakan bahwa curren ratio, return on asset, return on equity, total asset turn over, debt to equity ratio dan asset growth berpengengaruh secara simultan terhadap beta saham syariah. Berdasarkan hasil analisis pada tabel 4.28 dapat menunjukan nilai signifikansi untuk pengaruh current ratio, return on asset, return on equity, total asset turn over, debt to equity ratio, dan asset growth sebesar 0,208>0,05 dan nilai $\mathrm{F}_{\text {hitung }} 1,455<2,25\left(\mathrm{~F}_{\text {tabel }}\right)$. Sehingga dapat disimpulkan bahwa $\mathrm{H}_{\mathrm{a} 7}$ ditolak, yang berarti tidak terdapat pengaruh current ratio, return on asset, return on equity, total asset turn over, debt to equity ratio, dan asset growth secara simultan terhadap beta saham.

Berikut ini akan disajikan ringkasan hasil penelitian pada tabel berikut:

Tabel 4 Ringkasan Hasil Pengujian Hipotesis

\begin{tabular}{clc}
\hline No & \multicolumn{1}{c}{ Hipotesis } & Hasil \\
\hline 1 & Curren Ratio berpengaruh positif terhadap Beta Saham Syariah & Ditolak \\
\hline 2 & Return on Asset berpengaruh positif terhadap Beta Saham Syariah & Ditolak \\
\hline 3 & Return on Equity berpengaruh positif terhadap Beta Saham Syariah & Ditolak \\
\hline 4 & $\begin{array}{l}\text { Total Asset Turn Over berpengaruh positif terhadap Beta Saham } \\
\text { Syariah }\end{array}$ & Ditolak \\
\hline 5 & $\begin{array}{l}\text { Debt to Equity Ratio berpengaruh positif terhadap Beta Saham } \\
\text { Syariah }\end{array}$ & Diterima \\
\hline 6 & $\begin{array}{l}\text { Asset Growth berpengaruh positif terhadap Beta Saham Syariah } \\
\text { Curren Ratio, Return on Asset, Return on Equity, Total Asset Turn }\end{array}$ & Ditolak \\
\hline & $\begin{array}{l}\text { Over, Debt to Equity Ratio dan Asset Growth berpengaruh } \\
\text { berpengaruh positif terhadap Beta Saham Syariah }\end{array}$ & \\
\hline Suber: Olahan Penulis (2017)
\end{tabular}

Sumber: Olahan Penulis (2017) 


\section{KESIMPULAN}

Beta saham merupakan pengukur risiko sistematik dari suatu saham. Hasil penelitian terhadap 14 perusahaan menunjukkan bahwa pada periode Januari 2012 sampai dengan Desember 2016 beta saham yang diukur berdasar model pasar menghasilkan nilai $\beta<1$ yang berarti tingkat keuntungan saham perusahaan yang tergabung dalam Jakarta Islamic Index (JII) meningkat lebih kecil dibanding dengan kentungan keseluruhan saham di pasar. Ini menandakan bahwa risiko sistematis saham individual lebih kecil dibanding resiko sistematis pasar. Saham jenis ini sering disebut saham defensif.

Analisis data dengan regresi linear berganda untuk merumuskan hubungan antara beta saham sebagai variabel dependen dengan rasio profitabilitas, dan beta akuntansi sebagai variabel independen menghasilkan koefisien determinasi $\left(\mathrm{R}^{2}\right)$ sebesar $12,2 \%$. Hal ini menunjukkan variabel-variabel tesebut dalam menjelaskan perubahan beta saham mempunyai hubungan dan pengaruh pola lemah.

Pengujian secara simultan pengaruh current ratio, return on asset, return on equity, total asset turn over, debt to equity ratio, dan asset growth terhadap beta saham menghasilkan $\mathrm{F}$ statistik dimana $\mathrm{F}_{\text {hitung }}<\mathrm{F}_{\text {tabel }}$ dengan signifikansi $20 \%$, hal ini membuktikan bahwa pada tingkat signifikansi $5 \%$ variabel fundamental yang diajukan secara bersama-sama tidak berpengaruh signifikan terhadap beta saham.

Pengujian secara parsial pengaruh masing-masing variabel independen terhadap beta saham menunjukkan bahwa terdapa satu variabel yang mempunyai $t_{\text {hitung }}$ lebih besar dari $t_{\text {tabel }}$ dan signifikansinya lebih kecil dari 5\%, yaitu variabel debt to equity ratio. Sedangkan variabel current ratio, return on asset, return on equity, total asset turn over, dan asset growth tidak berpengaruh positif signifikan terhadap beta saham. Fenomena ini menunjukkan bahwa investor tidak terlalu memperhitungkan current ratio, return on asset, return on equity, total asset turn over, dan asset growth melainkan lebih memperhatikan debt to equity ratio.

\section{Implikasi dan Keterbatasan Penelitian}

Hasil perhitungan beta saham dalam penelitian ini yang merupakan rata-rata dari sampel yang digunakan menunjukkan nilai beta yang tidak terlalu tinggi karena lebih kecil daripada satu. Dengan nilai beta yang rendah ini maka dalam berinvestasi di pasar modal khususnya perusahaan yang tergabung dalam Jakarta Islamic Index (JII), setiap pemodal tidak perlu berpatokan pada beta saham saja dalam mempertimbangkan setiap alternatif investasi melainkan melihat pada faktor-faktor lain, seperti memasukkan variabel-variabel yang berasal dari laporan keuangan perusahaan dalam mempertimbangkan investasi yang akan dipilihnya.

Penelitian ini memiliki beberapa keterbatasan, antara lain sebagai berikut ini:

1) Variabel yang digunakan hanya beberapa faktor fundamental, sedangkan masih ada faktor fundamental lainnya, faktor teknikal, indikator perekonomian dan faktor-faktor yang lain yang dimungkinkan relevan terhadap beta saham.

2) Sampel yang digunakan relatif kecil dikarenakan terdapat beberapa perusahaan yang tidak memiliki laporan tahunan yang lengkap periode 2012 s/d 2016. 


\section{DAFTAR PUSTAKA}

Abdurahim, Ahim. 2003. Pengaruh Current Ratio, Asset Size, dan Earnings Variability terhadap Beta Pasar. Jurnal Akuntansi dan Investasi, (Online), Vol. 4 No. 2, hal: 44-62, Juli 2003. ISSN: 1411-6227

Ahmad, Kamaruddin. 2004. Dasar-Dasar Manajemen Investasi Dan Portofolio. Cetakan Kedua. Jakarta; PT. RINEKA CIPTA

Aprilia, Anita. 2014. Analisis Rasio Keuangan Untuk Mengukur Kinerja Keuangan Pada Koperasi Dhaya Harta Jombang. Jurnal Ilmu \& Riset Manajemen, (Online), Vol. 3 No. 2. Hal:1-15

Artha, Danika, Reka., Achsani, Noer, Azam., \& Sasongko, Hendro. 2014. Analisis Fundamental, Teknikal Dan Makroekonomi Harga Saham Sektor Pertanian. JMK, (Online), VOL. 16, NO. 2, ISSN 1411-1438. Hal:175-184.

Aruzzi, M. Iqbal., \& Bandi. 2003. Pengaruh Tingkat Suku Bunga, Rasio Profitabilitas, Dan Beta Akuntansi Terhadap Beta Saham Syariah Di Bursa Efek Jakarta. Simposium Nasional Akuntansi VI, (Online). Hal: 647-658

Antonio, M Syafii, Hafindhoh \& Hilman Fauzi. (2013). The Islamic Capital Market VolatilityA Comparative Study Between In Indonesia And Malaysia: Jurnal Liquidity Vol. 2, No. 1 hlm 1 - 12

Ash-Shidiq, Hafids., dan Setiawan, Aziz, Budi.2015. Analisis Pengaruh Suku Bunga Sbi, Uang Beredar, Inflasi Dan Nilai Tukar Terhadap Indeks Harga Saham Jakarta Islamic Index (JII) Periode 2009-2014. Jurnal Ekonomi dan Perbankan Syariah, Vol. 3. No. 2, ISSN (cet): 2355-1755. Hal: 25-46

Atmaja, Lukas, Setia. 2008. Teori \& Praktik Manajemen Keuangan. Edisi Pertama. Yogyakarta; ANDI

Beik, Irfan, Syauqi., Dan Fatmawati, Sri, Wulan. 2014. Pengaruh Indeks Harga Saham SyariahInternasional Dan Variabel Makro Ekonomi Terhadap Jakarta Islamic Index. Al-Iqtishad:Vol. VI, No. 2, Juli 201, (Online). Hal:155-178

Bursa Efek Indonesia. PENGUMUMAN Perusahan Komposisi Saham dalam Perhitungan Jakarta Islamic Index. www.idx.co.id

Corrado, Charles, J., and Jordan Bradford, D. 2000. Fundamentals of Investments: Valuation and Manajement. International Editions. Singapore: McGRAW HILL

Coryaina, Vina Rahmatika. 2013. Pengaruh Faktor Fundamental Perusahaan Ekonomi Makro Terhadap Risiko Investasi Saham Syariah.Proposal, (Online).

Chen, Ming. 2014. Analisis Pengaruh Perekonomian Makro Dan Mikro Yang Berpengaruh Pada Risiko Sistematis Saham. Jurnal Nominal, (Online), Vol. III, No. 2. Hal:75-100

Chairiyah, Mir'atul. 2013. Pengaruh Asset Growth, Return on Equity, Total Asset Turnove, dan Earning Per Share terhadap Beta Saham. Skripsi, (Online)

Fahmi, Irham. 2013. Analisis Laporan Keuangan. Cetakan Ketiga. Alfabeta, cv. Bandung

Firdaus, Bilqis, Anisa. 2013. Analisis Larangan Transaksi Short Selling Pada Pasar Modal Syariah Serta Dampak Negatif Yang Ditimbulkan Dalam Pasar Modal Konvensional. (Online), Hal:1-22

Gujarati, Damodar . 1988. Ekonometrika Dasar. Jakarta: Erlangga

Gunawan, Ade., \& wahyuni, Sri fitri. 2013. Pengaruh Rasio Keuangan TerhadapPertumbuhan Laba Pada Perusahaan Perdagangan Di Indonesia. Jurnal Manajemen \& Bisnis, (Online), Vol 13 No. 01 April 2013. ISSN 16937619

Gusni. 2015. Studi Tentang Pentingnya Analisis Fundamental Saham. SMART: Study Management Research, (Online), Vol. XII, No. 2. ISSN : 1693-4474

Harwaningrum, Miranti. 2016. Perbandingan Penilaian Saham Dengan Metode Analisis Fundamental Dan Analisis Tehknical, Penggorengan Saham, Serta Keputusan 
Penilaian Saham Jika Hasil Berlawanan Arah Untuk Kedua Metode Analisis Pada Saham Bakrie Group Untuk Periode 2005- 2009. Jurnal Ilmiah Manajemen Dan Bisnis, (Online), Volume 2, Nomor 1. Hal:138-149

Hamzah, Ardi. 2005. Analisa Ekonomi Makro, Industri Dan Karakteristik Perusahaan Terhadap Beta Saham Syariah. SNA VIII, (Online), Solo, 15 - 16 September 2005. SNA 267-378

Hantono. 2015. Pengaruh Current Ratio Dan Debt To Equity Ratio Terhadap Profitabilitas Pada Perusahaan Manufaktur Sektor Logam Dan Sejenisnya YangTerdaftar Di Bursa Efek Indonesia Periode 2009 2013. Jurnal Wira Ekonomi Mikroskil, (Online), Volume 5, Nomor 01. Hal:21-29

Husnan, suad. 1998. Manajeme Keuangan: Teori Dan Penerapan (Keputusan Jangka Pendek). Edisi Keempat, Cetakan Kedua. Togyakarta: BPFE

Herdiyana., \& Sinaga, Rosiana. 2011. Analisis Fundamental Terhadap Harga Saham Dalam Menarik Investor Pada PT. Bakrie Telecom, Tbk. Jurnal Ilmiah Manajemen dan Akuntansi Fakultas Ekonomi (JIMAFE), Volume Semester I 2011. Hal:1-10

Irawan, Repi, Putra. 2013. Penerapan Analisis Fundamental Dalam Menilai Investasi Saham Di Bursa Efek Indonesia. Jurnal Ilmu \& Riset Akuntansi, (Online), Vol. 2 No. 11. Hal:1-17

Jogiyanto. 2004. Metodologi Penelitian Bisnis. Cetakan Pertama. Yogyakarta: BPFEYogyakarta

Jogiyanto. 2003. Teori Portofolio dan Analisis Investasi. Edisi Ketiga. Yogyakarta: BPFE-Yogyakarta

Jazuli, A Muhammad., \& Witiastuti, Rini setyo.2016. Determinan Beta Saham Perusahaan Real Estate Dan Property Di Bei. Management Analysis Journal, (Online), Universitas Negeri Semarang. ISSN 2252-6552. Hal:64-70

Muljono. 2002. Analisis Faktor-Faktor Yang Mempengaruhi Risiko Sistematis Saham Industri Barang-Barang Konsumsi Pada Bursa Efek Jakarta. Tesis (Online). Program Studi Magister Manajemen Universitas Diponegoro.

Mulyadi, Dedi., Kosasih., dan Suhana, Taing. 2013. Analisis Rasio Keuangan pada Koperasi Karyawan Aneka Pangan Nusantara (KOPKANUS) PT Indofood CBP Sukses Makmur Tbk Purwakarta. Jurnal Manajemen, (Online), Vol.10 No.3. Hal: $1160-1177$

Munawir. 2004. Analisis Laporan Keuangan. Edisi Empat. Liberty: Yogyakarta.

Muizudin. 2015. Analisis Rasio Keuangan Sebagai Alat Untuk Menilai Kinerja Keuangan. Jurnal Ilmu Dan Riset Manajemen, (Online), Volume 4, Nomor 9. Hal:1-18

MB, Fatimatuz, Zuhro. 2016. Pengaruh Ukuran Perusahaan, Pertumbuhan Aset, Dan Profitabilitas Terhadap Struktur Modal. Jurnal Ilmu dan Riset Manajemen, (Online), Volume 5, Nomor 5.ISSN : 2461-0593

Ningsih, Fatmi R. (2010). Pengaruh Inflasi dan Pertumbuhan Ekonomi Terhadap Pengangguran Di Indonesia. Skripsi, Jurusan Ilmu Ekonomi dan Studi Pembangunan Fakultas Ekonomi dan Ilmu Sosial Universitas Islam Negeri Syarif Hidayatullah. Jakarta

Priatinah, Denies., \& Kusuma, Prabandaru, Adhe. 2012. Pengaruh Return On Investment (ROI), Earning Per Share (EPS), Dan Dividen Per Share (DPS) Terhadap Harga Saham Perusahaan Pertambangan Yang Terdaftar Di Bursa Efek Indonesia (BEI) Periode 2008-2010. Jurnal Nominal, (Online), Vol. 1, No. 1. Hal:50-64 
Pramono, Deny. 2015. Analisis Rasio Keuangan Untuk Menilai Kinerja KeuanganPerusahaan Pertambangan Mineral Dan Logam. Jurnal Ilmu dan Riset Manajemen, (Online), Volume 4, Nomor 11. Hal:1-16

Pusakasari, Ayu, Shinta. 2015. Regresi Panel Dengan Metode WeightedCross-SectionSur Pada Data Pengamatan Gross Domestic Product Dengan Heterokedastisitas Dan Korelasi AntarIndividu (Cross-Section Correlation). Jurusan Matematika, F.Mipa, Universitas Brawijaya. (Online). Hal: 477-480

Rahman, Fathur. 2015. Pengaruh Return on Asset (ROA), Net Profit Margin (NMP), dan Debt to Equity Ratio (DER) terhadap Harga Saham pada PT.Telekomunikasi Indonesia (Persero), Tbk. (Online). (http://sayangsurgaku.blogspot.co.id/?m=1/ , diakses 15 Agustus 2016)

Rubianti, Nana. 2013. Analisa Rasio Keuangan Untuk Menilai Kinerja Perusahaan Pada PT. Admiral Lines Cabang Tanjungpinang. Jurnal Akuntansi, (Online). Hal:1-17

Rhamadana, Recly, Bima. 2016. Analisis Rasio Keuangan Untuk Menilain Kinerja Keuangan Pada PT. H.M SampoernaTbk. Jurnal Ilmu Dan Riset Manajemen : Volume 5, Nomor 7, ISSN : 2461-0593. Hal:1-18

Rosyida, Ajeng, Gama. 2015. Perbandingan Tingkat Pengembalian (Return), Risiko Dan Koefisien Variasi PadaSaham Syariah Dan Saham Non Syariah Di Bursa Efek Indonesia (BEI) Periode 2011-2013. JESTT, (Online), Vol. 2 No. 4 April. Hal: 288-304

Rachmawati, Sisca. 2011. Analisis Pengaruh Faktor Fundamental Terhadap Risiko Sistematis (Beta) Pada Saham Lq 45 Yang Terdaftar Di Bursa Efek Indonesia (Bei) Periode 2006-2008. Jurnal Ekonomi, (Online). Hal:1-29

Ross, Stephen A., Westerfield, Randolph.,\& Jordan, Bardford D. 2008. Fundamental of Corporate Finance. 8th Edition. New York: McGraw-Hill.

Rusdin. 2008. Pasar Modal. Cetakan Kedua. Alfabeta, cv. Bandung

Sarwana, Jonathan., dan Martadiredja, Tutty. 2008. Riset Bisnis Untuk Pengambilan Keputusan. Edisi Pertama. CV, ANDI OFFSET. Yogyakarta

Soeroso, Anditya. 2013. Faktor Fundamental (Current Ratio, Total Debt To Equity Ratio, Total Asset Turn Over, Return On Investment) Terhadap Risiko Sistematis Pada Industri Food And Beverages Di Bursa Efek Indonesia. Jurnal EMBA, (Online), Vol.1 No.4 Desember 2013, Hal. 1687-1696. SSN 2303-1174

Sangkala, Abd.Azis. 2006. Analisis Kinerja Keuangan Berdasarkan Rasio Profitabilitas Pada Perusahaan Pabrik Roti Tony Bakery Pare-Pare. Jurnal Ekonomi Balance Fekon Unismuh Makassar. (Online), Hal:1-19

Setiawan, Doddy. 2003. Analisis Faktor-Faktor Fundamental Yang Mempengaruhi Resiko Sistematis Sebelum Dan Selama Krisis Moneter. Simposium Nasional Akuntansi VI, (Online). Hal:565-574

Suharli, Michell., \& Oktorina, Megawati. 2005. Emprediksi Tingkat Pengembalian Investasi Pada Equity Securities Melalui Rasio Profitabilitas, Likuiditas, Dan Hutang Pada Perusahaan Publik Di Jakarta. SNA VIII Solo, (Online). Hal:288296

Sutedi, Adrian. 2013. Pasar Modal. Cetakan Kesatu. Alfabeta, cv. Bandung

Sumaryono. 2013. Analisis Fundamental Saham Bumn Di Bursa Efek Indonesia (BEI). Jurnal Ekonomi, (Online), Vol. 6 Edisi 2, ISSN: 2302-7169. Hal:1-15

Syafei, Ade, Wirman. 2013. Analisis Pengaruh Penerapan Good Governance Bisnis Syariah (Ggbs) Terhadap Kemampulabaan (Studi Perusahaan Yang Terdaftar Di Jii 2011). Jurnal Al-Azhar Indonesia Seri Pranata Sosial, Vol . 2, No. 2, September . Hal: 74-86 
Utami, Ayu, Tri. 2016. Pengaruh Variabel Makro Ekonomi Terhadap Indeks Jakarta Islamic Index (JII) Periode Januari 2010 Hingga November 2015. Jurnal Ekonomi Syariah Teori Dan Terapan, Vol. 3 No. 1 Januari 2016: 70-84

Wulansari, Ida, Nur. 2014. Analisis Pengaruh Faktor-Faktor Fundamental Terhadap Beta Saham LQ-45 Di BEI. Jurnal Ilmu \& Riset Manajemen, (Online), Vol. 3 No. 6. Hal:1-15

Yafis, Muhammad. 2018. Saham Dan Pasar Modal Syariah: Konsep, Sejarah Dan Perkembangannya. Miqot, Vol. XXXII No. 2, (Online). Hal: 232-246 